\title{
The Tenth Annual Conference of the Society for Industrial Archeology
}

\section{Tom Leary}

\author{
Slater Mill Historic Site, Pawtucket, RI
}

The Society for Industrial Archeology (SIA) held its Tenth Annual Conference in Hartford, CT on 7-10 May 1981. Connecticut has a reputation as the breeding ground of Yankee ingenuity, and an excellent project recently described many of its surviving work places and other offspring from the mating of knowledge and capital (see Matthew Roth, Connecticut: An Inventory of Historic Engineering and Industrial Sites, SIA, 1981). Based on what was discovered by that inventory, conference participants passed two days ogling a series of metalworking and brass manufacturing plants in the Hartford area and the Naugatuck Valley. However, apart from these ritual bus tours, this SIA meeting struck a more decidedly academic pose than past gatherings in the presentation of papers and talks. Perhaps the clearest evidence of this new departure was the format of the plenary session on "Industrial Archeology and Labor History."

Jeremy Brecher (Brass Workers' History Project) showed a 1979 videotape made at Bevin Brothers' bell casting shop (East Hampton, CT) on one of the last occasions when their c. 1880 coal-fired pit furnaces were in use. He then recapitulated the manual skills required in this particular process and alluded to the development of the electric casting furnace as a managerial stratagem for usurping control over production. Laurence F. Gross (Merrimack Valley Textile Museum) drew on both physical and documentary evidence to examine the evolution of wool carding machines and the changing role of operatives in the carding room. Particularly intriguing was his assessment of the labor involved in building cards through his intrepretation of machinery components such as arches and poppet heads; these humble articles revealed a transition from craftsmanship in wood to factory production of iron parts. My own talk focused on a turn-of-the-century rod rolling mill whose crew still handles hot steel with tongs. I described the labor it required by coupling direc $₫$ observation of the operating mill with the comments of its keepers from local 5705, United Steelworkers of America; they had been gracious enough to look at slider of themselves in action. All three papers were accompanied by, if not actual' edicated on visual materials-not so much as a 
concession to superior entertainment value but rather to avoid the ambiguity and circumlocution that often plague verbal accounts of industrial processes.

In his commentary, David Montgomery (Yale University) affirmed that close scrutiny of capital equipment could certainly contribute to clarifying what went on behind factory walls during earlier stages of mechanized production. However, while hardware should be incorporated into the picture, he stressed that the collective exercise or transmission of skill and the relationship of different strata within the labor force to management still must occupy the foreground of study. Gary B. Kulik (National Museum of American History, Smithsonian Institution) delineated certain intellectual traditions which had appropriated either technology or its social effects as their particular route to professional advancement; these separate paths had rarely converged until the appearance of such recent studies as Merritt Roe Smith's Harpers Ferry Armory and the New Technology. He emphasized the pedagogical value of operating machinery and urged historians not to neglect the evocative potential of surviving industrial sites lest their craft suffer the sensory impoverishment that has beset sociology.

General discussion after the papers and comments was largely informed by personal experiences rather than current scholarly controversies. One theme which emerged was the incorporation of science and engineering into the process of production, rendering less formalized job skills and training redundant. For example, it was noted that more sophisticated product specifications contributed to the ascendancy of the open hearth steel process over wrought iron puddling (Bessemer converters were not mentioned). Another issue broached was the (inadvertent) exploitation of workers solely for memories of their vanishing occupations by historians endeavoring to interpret the industrial epoch now drawing to a close: Minerva's owl wheels among the vultures over Youngstown.

Though the afternoon sessions did not treat the cross-pollination of labor history and industrial archeology so explicitly, such issues were addressed in (at least) two presentations. Charles K. Hyde (Wayne State University) and Larry D. Lankton (Smithsonian Institution and Historic American Engineering Record) studied responses to the introduction of two different air-powered rock drills in the Michigan copper mining district. The 1880 s Rand drill provoked no documented resistance; the c.1910 one-man drill undermined established production groups and caused a major strike. Carolyn C. Cooper (Yale University) sought to reconstitute work on one of the earliest mechanized production lines, the 1805 naval pulley-block mill at Portsmouth Dockyard. She concluded that whatever regimentation may have existed was not dictated by the requirements of the machinery and layout.

Most participants felt that such gatherings do have potential for melding different approaches to the industrial past and the material situation at the point of production. Whether future conferences will tap that potential remains an open question. 